\title{
Sadhukarn Song, the Song in Thai Rituals
}

\author{
Dheeraratn Srichuangchote, Dusanee Phasukdee, Tawich Kulawong and Nitipan Suwat
}

\begin{abstract}
This research purposed to study background and opportunity of performing Sadhukarn song with the process of ethnomusicology. The conclusion is as follows: Sadhukarn song is ancient and no one knows who the composer is and when they were composed. Most songs' histories legendarily link to Buddhism and Hinduism together. The songs mention the event that Shiva performs his power to the Buddha by playing hide and seek and he is defeated because the Buddha transformed into an atom, hiding at the tip of Shiva's hair. In consequence, Shiva is incapable of searching for him. At the end, Shiva must arrange a musical group to pay respect to Sadhukarn song. Sadhukarn is the song that means to pay respect to the three refuges and the great deities. It connects to the belief in Buddhism and Hinduism. The opportunity to perform the song is appropriate for rituals. In terms of Thai classical music, to perform Sadhukarn song is for the propitious ceremonies that are sacred. The sacred ceremonies are as follows: 1) royal ceremonies: royal celebration of birth ceremony, royal ordination ceremony, the Royal Kathina Ceremony, the Royal Ploughing Ceremony, Visakha Bucha ceremony, the Royal Ceremony to change gold seasonal attire of the Emerald Buddha, Celebration for His Majesty the King's Birthday Anniversary, and Royal cremation ceremony. 2) General ceremonies: ordination ceremony, house-blessing ceremony, Kathina ceremony, robe offering ceremony, traditional mahajati preaching, and the ceremony of paying homage and respect to music teachers. Moreover, they are applied as the first song to learn Thai classical music.
\end{abstract}

Keywords - Sadhukarn Song, Thai Rituals.

\section{INTRODUCTION}

In the present way of life, an individual is incapable of fleeing from the influence of music. No matter what they are doing, where they are, and when, the music is all around in every place and time. Music, therefore, is valuable to the way of human's life. The human's society in the past is simple. Their lifestyle is not complicated. Men receive the influence from environments and things that always change, building the evolution in many aspects of daily life, tradition, and arts, all evolve together. Apart from the society and environment, the human is a part of the changeable mechanism as well. (Surasak Jamnongsarn.1999:1).

Music is always developed, from one generation to one generation. Because people in every era or every group differently learn and receive knowledge and ideas from the environment, culture, customs, and tradition, resulting in the different of music in times and society. (Srisuk Wullipodom..1992:2). Thai classical music has been inherited

Dheeraratn Srichuangchote, Dusanee Phasukdee, Tawich Kulawong and Nitipan Suwat all are with the Music Department, Faculty of Humanities and Social Sciences Kanchanaburi Rajabhat University, Thailand from the past to the present day and has been developed with Thai people's lifestyle for all along. Thai classical music takes the great role in many people's activities, such as religious rituals, favorable and unfavorable rituals, royal ceremonies, entertainment, performances, and amusements (Nittaya Rusamai. 2009:1)

Sadhukarn is the important song that relates to many rituals, royal ceremonies, and general ceremonies. Its significant role has been inherited since the ancient days. In the present day, they are regarded as the high-class music. Old masters composed the songs to pay homage and respect, to be performed in the sacred opportunity; furthermore, the songs are originated from the legend about Buddhism and Hinduism. In Thai classical music society, they use these songs to play in the Buddhist rituals, for example, when the president lights the candles to worship the three refuges while the monks do the preaching. (Narongchai Pidokrajt. 1991:1). As aforementioned, the author interests in studying background and opportunity to perform Sadhukarn song with the purpose to conserve Thai music as the national art and culture through the later time.

\section{Methodology OF RESEARCH}

The study of background and opportunity to perform Sadhukarn song was a qualitative research in ethnomusicology. The first method is to do the in-depth interview with national artists in Thai classical music. The objective of an interview is to talk with someone to learn about something in - depth from the person's point of view, which is very useful and typical and they are very flexible. In an interview, the researcher meets with the interviewee in person. After the participatory observation, the researcher observed the behavior and the act of the phenomenon which the author is interested in studying and recorded for the description, analysis, and interpretation of its meanings. For the observation, the researcher applied the experience and interpretations (of events, persons, or acts) to access the results and conclusion. Information received from documents, textbooks, research, and articles about the background and opportunity to play Sadhukarn song in rituals would be analyzed and presented in the descriptive analytical research. 


\section{RESULT}

\section{A. Background of Sadhukarn Song}

According to the study of documents that relate to the background of Sadhukarn song, the history is as follows: Narongchai Pidokrat, stated about the history in Encyclopedia of Thai music (1999:427) that Sadhunkarn and Phleng na-phat are the first songs in the evening prelude set meaning the homage and respect towards the sacred three refuges, deities, and teachers and masters. The chance to perform Sadhukarn is when the monks do the preaching when the dancers play the role of holy people such as hermit, angel, hero, heroine, and giants. Moreover, it is used as the theme song of Thossaphon chapter in the great preaching ceremonies (Maha Jakata). The type of Sadhunkarn song is to start hitting the two-faced drum and then Ra-nat Ake by playing the ending melody as the prelude. After that, the other instruments will play. The ending is called "Sadhukarn Tiew-Noi or gods open the world, using the rhythm overlaying specifically, which is called "Tha."

Sangad Phukhaotong (1991:94) said about Sadhukarn song in the article the access to Thai music in the 16th Thai music fair in Matthayom level that, for Sadhunkarn song, it is regarded as the high-class Phleng na-phat which Thai classical musicians must pay homage and account the song of the master. The deprivation of homage might lead the musicians to self-disaster. For this reason, the students or the beginner will practice this song. Most play with the large circle Gong, using the instrument inherited from their teacher. The students must learn with homage and attention if they lack attention, it might lead them to self-disaster. However, if the students are able to learn until the end of the song and the can remember all the phases; they can remember the other songs because the other songs are included in Sadhunkarn song. In addition, the song also mentions the background which is amazingly strange than the other songs. Indeed, as Thai music teachers regulate many conducts towards Sadhukarn song; this is their psychological method because to perform the song with Piphat requires the good memory which is very important for the performers.

As for the difference of Sadhukarn song from the other songs, one typical characteristic is the lyrics are prose. The tune created by Thai composers is similar to the composition of literature as they consist of verse and prose. We can mesmerize verse better than prose because we depend on the rhyme so we can recall the later message from the verb and the sound without recalling the meaning. Thus, it gives us the chance to guess correctly. For prose, it is harder to guess. Like Sadhukarn song, it is a prose. Therefore, the ending sound of the message will not link to the next sentence. In other words, one sentence ends solely, without rhyme or relation to the next sentence. For this reason, it is quite hard to remember but it does not overdo. As a result, Sadhunkarn song is similar to the song for testing ability and memory for the students who begin to learn Piphat instruments.

Additionally, the beliefs about its history are as follows: Jan Tovisuth mentioned "the background of Sadhunkarn song" in the third Thai classical music book for Matthayom Level
(1977: 12-13) that when the Lord Buddha reached the enlightenment in the Buddhist era. His fame and high reputation spread in the three worlds. One day, the group of angels ascended from heaven in order to listen to the preaching in front of the Lord Buddha and the heaven was silent because all the angels were not there. When Shiva deity went out for the deity meeting, no other deities and angels welcome him. There were some but a few. The great deity was suspicious so he asked Nonthi deity and the anger consumed after the realization, including the Buddha. He asked Uma (Parvati) goddess and Nonthi to visit the human world. As he saw the other gods and angels listening to the preaching, Shiva, Uma, and Nonthi, including his angelic servants began to dance and entertain loudly aiming at destroying the attention of the deity in the Dhamma circle. With the holy power of the Lord Buddha or the other, no one heard the annoying sound but they listened calmly. Shiva the great god was amazed so he entered inside and faced the Lord Buddha. The god challenged him to play hide and seek. The Lord accepted the challenge and kindly asked the god to hide first because he was the challenger. Shiva transformed himself into dust and hid himself in the jewel on the top of Brahma's palace. Due to his wonderful insight, the Lord Buddha let the other divine beings see too. Shiva hid himself three times and the last time, he hid in the underworld. The Buddha could find him and let the other see his power. When it was his turn to hide, he transformed himself into an atom hiding at the tip of Shiva's hair. Shiva used his radar to search for him everywhere but could not find the Buddha so he surrendered. When the great lord heard his surrender, he released his aura and went out of the hiding place. He came out of the hair of Shiva. Even though Shiva lost, he still had pride. In order to let the great god abandon the pride, the Buddha did not get out of the hiding place but stay at his hair even though he was persuaded, he would not move. The Buddha said if Shiva really surrendered to him, the great god must arrange the musical band to pay the homage for him. With this condition, he would get out of the hiding place. Shiva must accept and find the musical band to play the song as paying homage to Buddhism which is called "Sadhukarn." And the Lord Buddha appeared. As a result, this turns to a tradition that we must play music for paying homage or respect with Sadhukarn song. The song is regarded as the song of the sacred song, the same way we offered flower and candle-lights to pay respect.

Sompop Khamprasert stated about the history of Sadhukarn song in the book, how to learn music and play it well, (1989:23) that in the Buddhist era, Bodhisattva reached Arahant and Nirvana, resulting in the happiness and peacefulness of the three worlds. One day, Indra deity would like to arrange the deity meeting but the other gods did not attend so he asked the other god in the meeting and realized that the absent gods were listening to the Buddha's preaching. He was angry and envy. The god would like to play the lord Buddha to see his power and the challenge began. They played hide and seek and the result was Indra's defeat. In Buddhism, 
"Hide and Seek Posture" was created due to this legend. When the great lord received the victory, Indra summoned the lord to appear but as Buddha saw his pride, he turned indifferent to the summoning. Indra must order the gods and angels to pay homage to him; therefore, the great lord appeared. At that time, he was respected as the great founder and the great master of gods, angels, and humans.

Samran Koedpon, a National Artist (Thai classical music) of the year 2005, (Samran Koedpon.2017: Interview), said about Sadhukarn song that it is a Phleng na-phat included in the the morning prelude, the evening prelude, and the overture for preaching. This song is very significant to Thai musicians, especially those who are in Piphat because the beginner must learn to practice this song before the others, specifically those who study Piphat instrument. The teacher will catch the student's hands to hit the large circle Gong to play Sadhukarn, hitting the beginning of the music three times before continuing the song until the end. When they are fluent, they can play the other songs. The reason is the melody of the large circle Gong in Sadhukarn is the basic lesson. When they can play the song fluently, they can learn the other songs such as Tra Homrong, drum songs, and ching song, and others.
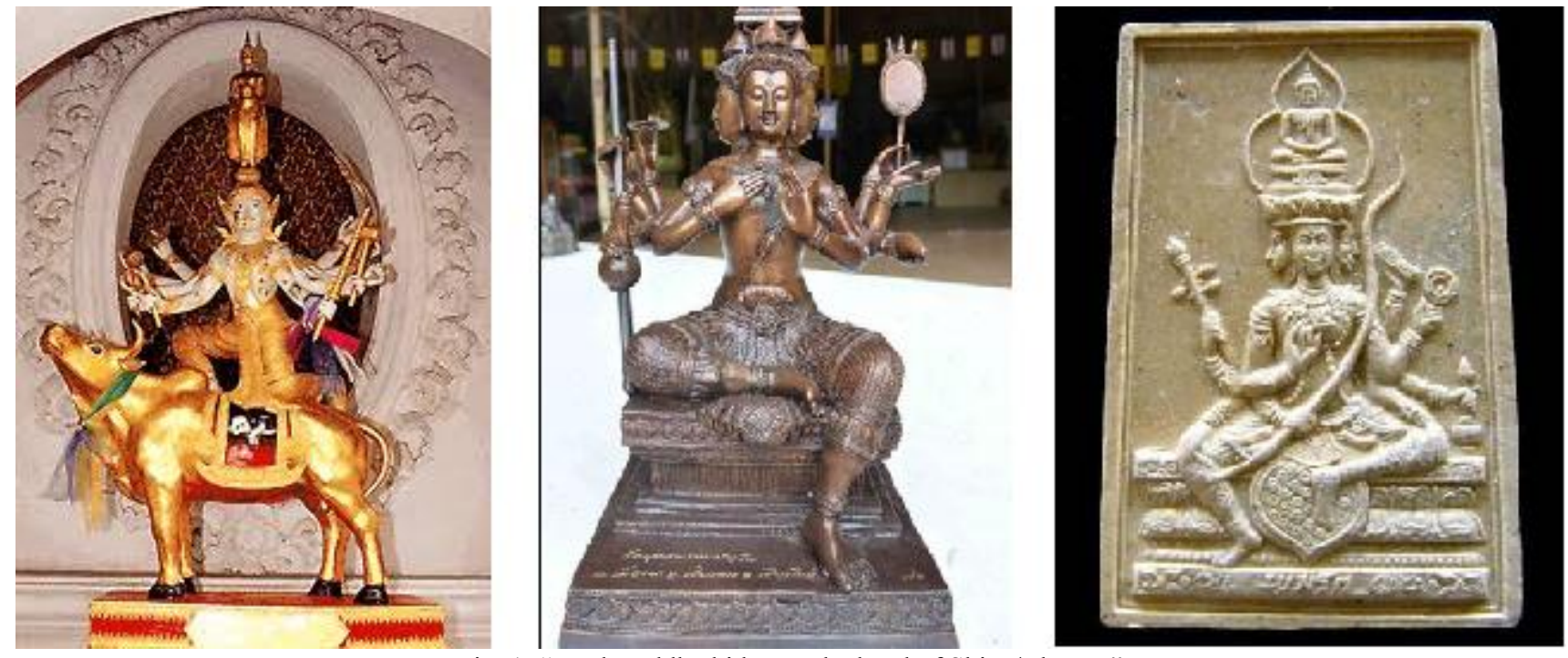

Fig. 1: "Lord Buddha hides on the head of Shiva/Bhrama"

\section{B. Opportunity of using Sadhukarn Song}

Thai music is important to Thai people's daily life, from birth to death, relating to traditions and rituals which cannot be separated. The music used in rituals can be divided into 2 types which are royal ceremonies or general ceremonies. According to the study of customs and rituals, it was found that Sadhukarn song has been used in these following rituals and ceremonies:

\section{- Sadhunkarn in Royal Ceremonies}

To perform Sadhukarn in royal ceremonies, the researcher collected data from Master Jiras Archnarong, Thai music specialist (Orchestra Artist level 8), Thai orchestra group, Office of Performing Arts of Fine Art Department, and a National Artist in Thai musical performance of the year 2002. Master Jiras Archnarong (Jiras Archanarong.2017: Interview) gave important information about Sadhunkarn song used in the royal ceremonies as follows:

1) Royal Celebration of Birth Ceremony

When the queen consort is about to giving birth, Prakhom officers who are positioned to

play trumpet, conch shell, and piphat received the signal from the medic team and Bureau of the Royal Household, they will hit the victory Gong and the other will start playing Sadhukarn song.
2) Royal ordination ceremony

Due to the fact that all Thai kings are the great Buddhist and the Buddhist supporter, when

the time comes, he must enter the ordination. Piphat band will play Sadhukarn song when he turns to monkhood.

3) Royal Kathina Ceremony

This royal ceremony is when the king goes to offer Kathina or appoint the representative to do the activity. In the royal ceremony, Piphat band and trumpet and conch shell band will start playing when they see the king arrives at Ubosot. The trumpet and conch shell band start playing first followed by Piphat who plays the slow rhythm song until the king prostates the Buddha image and returns to the royal seat, the song stops. Next, when the king lights the candles to worship the three refuges. Before he offers Kathina, the officer will hit the bell to give the signal and Piphat band will perform Sadhukarn song until the officer hit bell again, the band must stop playing.

4) Royal Ploughing Ceremony

This ceremony takes two days. On the first day of royal ploughing ceremony will be organized at Ubosot of Wat Phra Kaew in the grand palace. Piphat band will perform Sadhukarn song while the king or his representative lightes the candles to worship the three refuges. On the second day, the ceremony begins at the morning in 
Sanum Luang. The king will appoint Permanent Secretary for Ministry of Agriculture and Cooperatives to be Phraya Raek Na. In the ancient days, while Phraya Raek Na performed the ritual, ploughing, and sowing or other activities, there would be no piphat performing. Later in the reign of King Rama 9, Piphat musical band has been included in the ritual. When Phraya Raek Na makes a wish and picks up the panung which has 3 sizes available. The music band will play Sadhukarn song.

5) Visakha Bucha ceremony

Visakha Bucha ceremony is arranged at Wat Phra Kaew in the grand palace, the 14th day of the waxing moon in the 6th lunar month. Piphat band will perform Sadhukarn while the monk receives the fabric. And on the 15th day of the waxing moon in the 6th lunar month, Piphat band will perform this song during the patriarch does the preaching.

6) Royal Ceremony to change gold seasonal attire of the Emerald Buddha

Royal ceremony to change gold seasonal attire of the Emerald Buddha has been organized three times a year.

- Hot season, the 1st waning moon in the 4th lunar month or around March

- Rain season, the 1st waning moon in the 8th lunar month or around July

- Cold season, the 1st waning moon in the 12th lunar month or around November

Piphat will perform Sadhukarn song while the king or his representative takes off

the seasonal attire.

7) Celebration for His Majesty the King's Birthday Anniversary

Piphat will perform Sadhukarn song while the king lights the candles to worship the three refuges.

8) Royal cremation ceremony
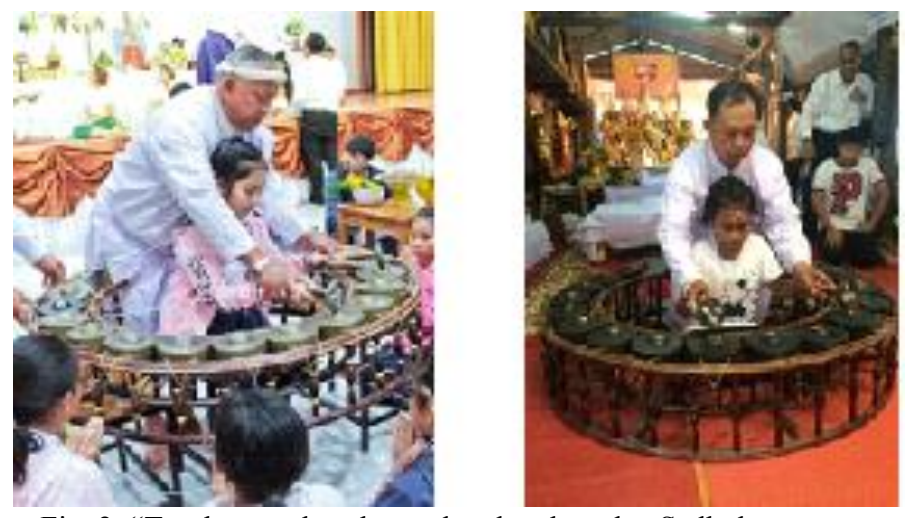

Fig. 2: "Teacher catches the student hand to play Sadhukarn song with the large circle Gong"

\section{- Sadhunkarn in General Ceremonies}

For the ceremonies of general people, the author interviewed Samran Koedpon, a National Artist in Thai classical music of the year 2005. Samran Koedpon (Samran Koedpon.2017: Interview) explained about Sadhukarn in the normal ceremonies as follows: People play Sadhukarn song in the auspicious ceremonies such as house-blessing ceremony, Maha Jakata. The ritual begins with the performance of Piphat playing the morning prelude, the evening prelude which includes Sadhukarn song. When it is time for Sangha ritual, the song will be performed during the lighting of candles. In Maha Jakata, it is the theme song of Thossaphon chapter in the great preaching ceremonies, which is the first chapter. When Thossaphon chapter ends, piphat continues playing the song.

Moreover, it has been played during the ceremony of paying homage and respect to music teachers and is the first song that Thai music teachers teach their students, due to the fact that the melody covers Gong or the basic main melody for continuing studying the next songs. Regarding the old tradition, the Thai musical students, especially the musicians in Piphat must learn Sadhukarn song first and the teacher will catch their hand to play the large circle Gong at the first verse of the song for three times. After that, the students will learn the song until the end and they will continue learning the other songs.

\section{CONCLUSIONS}

Sadhukarn is an old song without the name of the composer and the time of its creation is still a mystery. According to the legend of its history, the story is about the battle between the Lord Buddha, the founder of Buddhism, and the high god of Hinduism. There are Shiva, Bhrama, and Indra. They played hide and seek to test each other's power and the great lord won the gods. The deity must perform Sadhukarn song to summon the great lord out of the hiding place. In regards to the legend, Sadhukarn song relates to Buddhism and Hinduism which means to pay homage and respect to the three refuges and sacred beings. Therefore, the old masters in Thai music perform this song in the religious ritual or sacred ritual or auspicious ritual. In addition, it is the first song to practice with the large circle Gong before learning the other songs.

\section{A. Opportunities of the performance}

Sadhukarn song is the song performing in royal ceremonies and general ceremonies which can be concluded as follows:

\section{- Sadhunkarn in General Ceremonies}

- Royal Celebration of Birth Ceremony

- Royal ordination ceremony

- Royal Kathina Ceremony

- Royal Ploughing Ceremony

- Visakha Bucha ceremony

- Royal Ceremony to change gold seasonal attire of the Emerald Buddha

- Celebration for His Majesty the King's Birthday Anniversary

- Royal cremation ceremony

\section{- Sadhunkarn in General Ceremonies}

- General auspicious rituals: house-blessing ceremony 
- Kathina Ceremony

- Robe offering ceremony

- Great preaching ceremonies

- Ceremony of paying homage and respect to music teachers

It is evident that Sadhukarn song is an important song that has been used in royal ceremonies and general ceremonies which the meaning demonstrates homage and respect to the sacred beings: the three refuges, gods and goddess, and ancient masters.

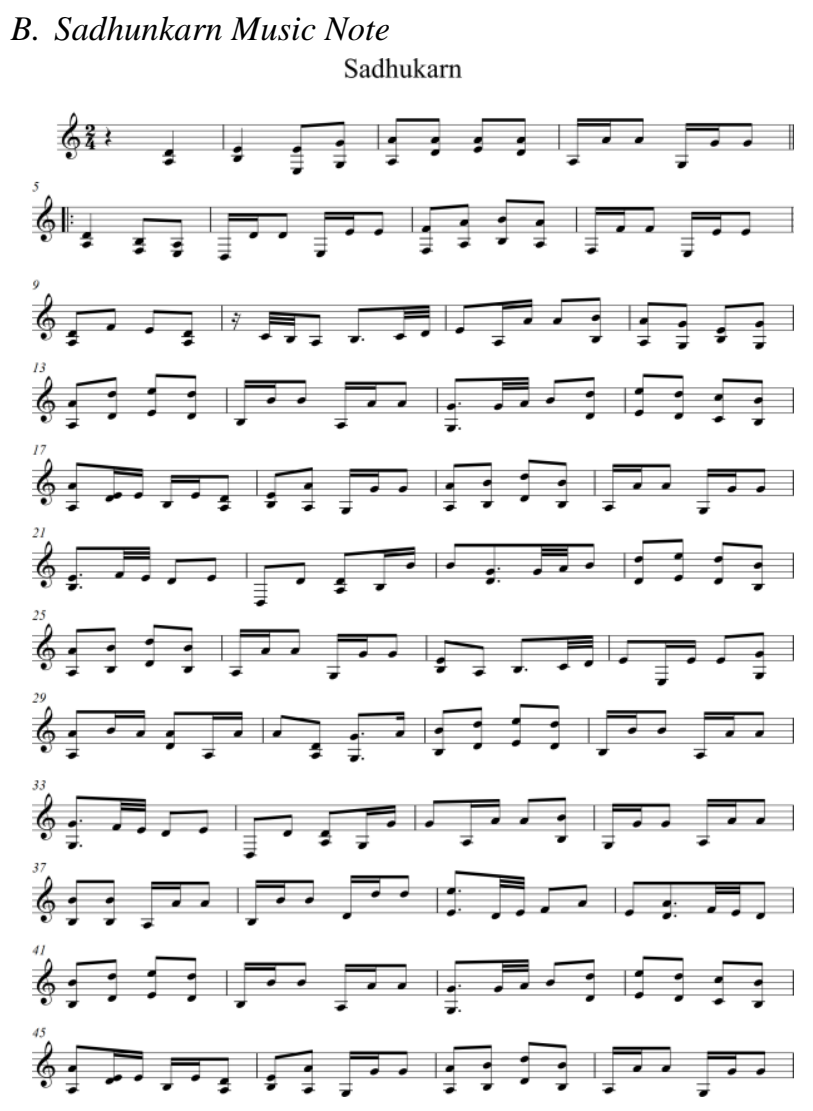

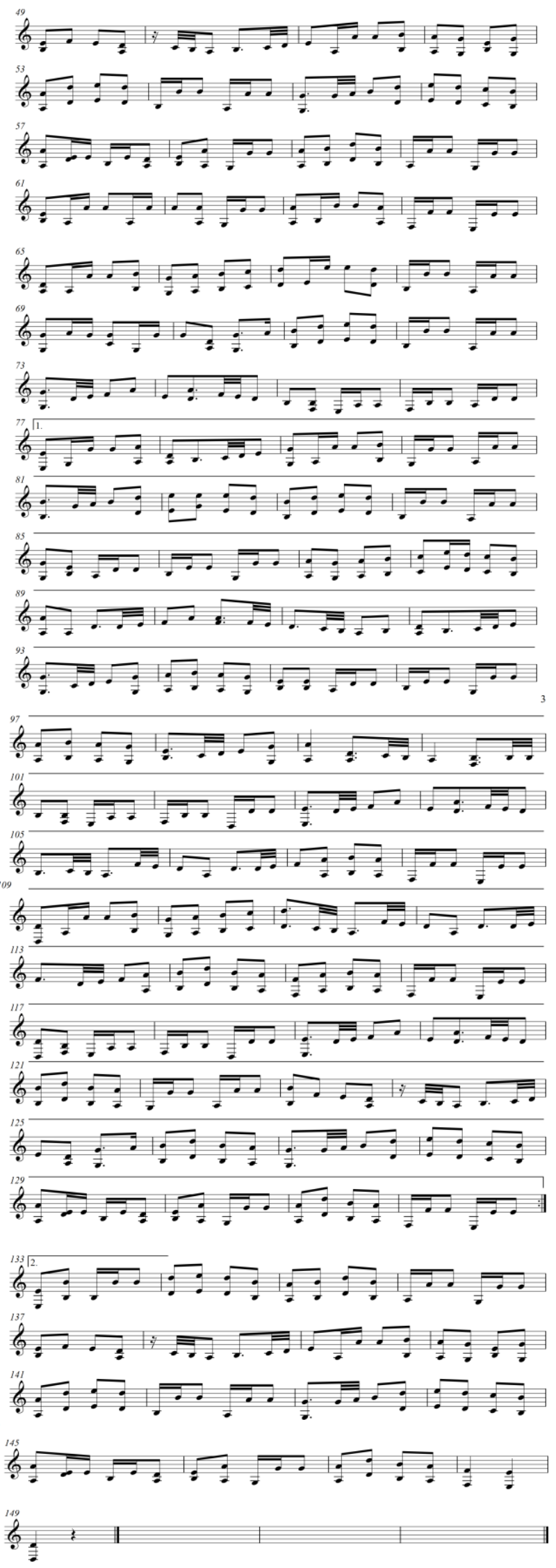




\section{ACKNOWLEDGEMENTS}

We would like to express the deepest appreciation to Kanchanaburu Rajabhat University where has given valuable support and special thank you to a National artist in thai musical performance who gave a precious information.

\section{REFERENCES}

[1] Jan Tovisuth. The background of Sadhunkarn song in the third Thai classical music book for Matthayom Level.,

(n.p.), 1977

[2] Jiras Archanarong. A National Artist in Thai musical performance of the year 2002. Interview, 10 May 2017.

[3] Narongchai Pidokrajt. Sadhukarn : Analysis of the Gong Wong Yai Melody. Master of Arts, Mahidol University, 1991.

[4] Narongchai Pidokrajt. Encyclopedia of Thai Song. Bangkok: Ruenkaew Printing, 1999.

[5] Nittaya Rusamai. A Study of Melody Sarathee. Master of Fine Arts in Ethnomusicology, Sinakharinwirot University, 2009.

[6] Srisuk Wullipodom. Music and Classical Dance of The Royal. Bangkok: Bangkok Bank, 1992

[7] Sompop Khamprasert. How to learn music and play it well. Nakhon Pathom: Silpakorn University (Nakhon Pathom Campus), 1989

[8] Sangad Phukhaotong. The access to Thai music in the 16th Thai music fair in Matthayom level. Bangkok: P.N. Printing Company, 1991

[9] Surasak Jamnongsarn. A study of Ranard Ek variations in Pleng Pae Sam Chanan. Master of Fine Arts in Ethnomusicology, Sinakharinwirot University, 1999.

[10] Samran Koedpon. A National Artist in Thai musical performance of the year 2005. Interview, 27 February 2017. 